\title{
The Carbon Source Controls the Secretion and Yield of Polysaccharide-Hydrolyzing Enzymes of Basidiomycetes
}

\author{
Eka Metreveli, Tamar Khardziani and Vladimir Elisashvili *(D) \\ Institute of Microbial Biotechnology, Agricultural University of Georgia, 0131 Tbilisi, Georgia; \\ e.metreveli@agruni.edu.ge (E.M.); t.khardziani@agruni.edu.ge (T.K.) \\ * Correspondence: v.elisashvili@agruni.edu.ge
}

Citation: Metreveli, E.; Khardziani, T.; Elisashvili, V. The Carbon Source Controls the Secretion and Yield of Polysaccharide-Hydrolyzing Enzymes of Basidiomycetes. Biomolecules 2021, 11, 1341. https:// doi.org/10.3390/biom11091341

Academic Editors: Daniel Kracher, Anna Pawlik and Grzegorz Janusz

Received: 17 August 2021

Accepted: 7 September 2021

Published: 10 September 2021

Publisher's Note: MDPI stays neutral with regard to jurisdictional claims in published maps and institutional affiliations.

Copyright: (c) 2021 by the authors. Licensee MDPI, Basel, Switzerland. This article is an open access article distributed under the terms and conditions of the Creative Commons Attribution (CC BY) license (https:// creativecommons.org/licenses/by/ $4.0 /)$.

\begin{abstract}
In the present study, the polysaccharide-hydrolyzing secretomes of Irpex lacteus (Fr.) Fr. (1828) BCC104, Pycnoporus coccineus (Fr.) Bondartsev and Singer (1941) BCC310, and Schizophyllum commune Fr. (1815) BCC632 were analyzed in submerged fermentation conditions to elucidate the effect of chemically and structurally different carbon sources on the expression of cellulases and xylanase. Among polymeric substrates, crystalline cellulose appeared to be the best carbon source providing the highest endoglucanase, total cellulase, and xylanase activities. Mandarin pomace as a growth substrate for $S$. commune allowed to achieve comparatively high volumetric activities of all target enzymes while wheat straw induced a significant secretion of cellulase and xylanase activities of I. lacteus and P. coccineus. An additive effect on the secretion of cellulases and xylanases by the tested fungi was observed when crystalline cellulose was combined with mandarin pomace. In I. lacteus the cellulase and xylanase production is inducible in the presence of cellulose-rich substrates but is suppressed in the presence of an excess of easily metabolizable carbon source. These enzymes are expressed in a coordinated manner under all conditions studied. It was shown that the substitution of glucose in the inoculum medium with Avicel provides accelerated enzyme production by I. lacteus and higher cellulase and xylanase activities of the fungus. These results add new knowledge to the physiology of basidiomycetes to improve cellulase production.
\end{abstract}

Keywords: wood-rotting basidiomycetes; carbon source; cellulase; regulation of synthesis; saccharification

\section{Introduction}

Plant biomass is abundant, renewable, rich in carbohydrates, and the most suitable resource for large-scale production of bioenergy and various organic chemicals [1,2]. It is a cheap but complex material consisting of polymers of cellulose, hemicellulose, and lignin; therefore, a wide range of hydrolytic and oxidative enzymes is required for their degradation. Hydrolysis of biomass polysaccharides into fermentable sugars by cellulases and hemicellulases is the key step for enzymatic conversion of lignocellulose [1-4]. Cellulases comprise endoglucanases (EC 3.2.1.4) which cleave internal $\beta$-1,4-glucosidic bonds of cellulose chains, exoglucanases (EC 3.2.1.91) which processively act on the reducing and non-reducing ends of cellulose to release short-chain cello-oligosaccharides, and $\beta$ glucosidases (EC 3.2.1.21) which hydrolyze soluble cello-oligosaccharides to glucose. As far as hemicellulases are concerned, endo- $\beta-1,4$-xylanases (EC 3.2.1.8) and $\beta$-xylosidases (EC 3.2.1.37) and auxiliary enzymes are required for their complete hydrolysis.

Cellulases are widely used in biofuel, food and feed, textile, paper-pulp, cosmetics, chemicals, and other industries [1,2]. The main challenges for wide and large-scale application of cellulases and xylanases remain the reduction of their cost and the development of more efficient enzyme cocktails with high specific activity and stability $[3,4]$. Wooddecomposing white-rot basidiomycetes (WRB) are excellent producers of enzymes that deconstruct the cell wall of plants [5]. Due to their ecological and biological peculiarities, they are highly adapted to different environments and resources. Moreover, some of them 
have shown exceptional potential for the production of individual groups of hydrolytic enzymes under appropriate cultivation conditions. Thus, Coprinellus disseminatus produced $469 \mathrm{U} / \mathrm{mL}$ of alkali-thermotolerant xylanase along with negligible cellulase activity [6] while Armillaria gemina secreted up to $146 \mathrm{U}$ endoglucanase $/ \mathrm{mL}, 15 \mathrm{U} \beta$-glucosidase $/ \mathrm{mL}$, and $1.72 \mathrm{U} \mathrm{FPA} / \mathrm{mL}$ [7]. Further, Jagtap et al. [8] achieved very high $\beta$-glucosidase activity $(45.2 \mathrm{U} / \mathrm{mL})$ in the submerged cultivation of Pholiota adiposa in a medium containing rice straw and corn steep powder. High cellulase and xylanase activities were revealed in submerged cultivation of Irpex lacteus and Schizophyllum commune $[9,10]$. However, unlike soft rot ascomycetes, such as Trichoderma reesei and Aspergillus niger, which are the most studied cellulolytic fungi and widely used in biorefinery microorganisms, the physiology of cellulose degradation and mechanism of cellulases synthesis regulation in WRB remains poorly understood. Therefore, more in-depth studies are required to understand how specific environmental factors modulate the secretion of individual cellulases and xylanase to develop the fungus enzyme system and technological process for their industrial application.

In the present work, profiles of the polysaccharide-hydrolyzing secretomes of three saprotrophic WRB species were analyzed in their submerged cultivation to elucidate the effect of chemically and structurally different carbon sources on the expression of cellulases and xylanase and to establish substrate specificities and enzyme production patterns of the tested fungi. The results obtained contribute to a better understanding of the effect of the type of lignocellulosic biomass and carbon source on the induction/repression of cellulolytic enzymes.

\section{Materials and Methods}

\subsection{Organisms and Inoculum Preparation}

Irpex lacteus (Fr.) Fr. (1828) BCC104, Pycnoporus coccineus (Fr.) Bondartsev and Singer (1941) BCC310, and Schizophyllum commune Fr. (1815) BCC632 isolated from tree branches in the forests of Georgia and deposited in the basidiomycetes culture collection of the Institute of Microbial Biotechnology have been used in this study. The fungal inocula were prepared by growing the mycelia on a rotary shaker (New Brunswick Scientific, Edison, NJ, USA) at $160 \mathrm{rpm}$ and $27^{\circ} \mathrm{C}$ in $250 \mathrm{~mL}$ flasks containing $100 \mathrm{~mL}$ of standard medium (SM) (g/L): glucose-15.0, $\mathrm{KH}_{2} \mathrm{PO}_{4}-1.0, \mathrm{~K}_{2} \mathrm{HPO}_{4}-0.2, \mathrm{MgSO}_{4} \cdot 7 \mathrm{H}_{2} \mathrm{O}-0.5$, peptone-3.0, yeast extract-3.0, $\mathrm{pH}$ 6.0. After 7 days of fungal cultivation mycelial pellets were harvested and homogenized using a Waring laboratory blender (Waring Commercial, Torrington, CT, USA).

\subsection{Cultivation Conditions}

Submerged cultivation of fungi was carried out using rotary shakers Innova 44 (New Brunswick, NJ, USA) at $160 \mathrm{rpm}$ and $27^{\circ} \mathrm{C}$ in $250 \mathrm{~mL}$ flasks containing $100 \mathrm{~mL}$ of the medium of following composition $(\mathrm{g} / \mathrm{L}): \mathrm{KH}_{2} \mathrm{PO}_{4}-1.0, \mathrm{~K}_{2} \mathrm{HPO}_{4}-0.2, \mathrm{MgSO}_{4} \cdot 7 \mathrm{H}_{2} \mathrm{O}-0.5$, peptone-7.0, yeast extract-5.0, $\mathrm{pH}$ 6.0. Crystalline cellulose at a concentration of $15 \mathrm{~g} / \mathrm{L}$ and milled to powder wheat straw, beech sawdust, wheat bran, and mandarin squeeze obtained from the juice manufacturing company in Kobuleti were used at a concentration of $40 \mathrm{~g} / \mathrm{L}$ as carbon sources. Moreover, the effect of adding glycerol to the 1.5\% Avicel-containing medium on enzyme synthesis was assessed in special experiments.

During the fungus cultivation, at predetermined time intervals, $1-2 \mathrm{~mL}$ samples were taken from the flasks, the solids were separated by centrifugation at $10,000 \times g$ for $10 \mathrm{~min}$ at $4{ }^{\circ} \mathrm{C}$ and the supernatants were analyzed for $\mathrm{pH}$, reducing sugars, and enzyme activities.

\subsection{Cultivation in a Fermenter}

To scale up the cellulase and xylanase production by I. lacteus, one cultivation of the fungus was performed in the $7 \mathrm{~L}$ fermenter LiFlus GX (Biotron, Incheon, Korea) equipped with $\mathrm{pH}$, temperature, $\mathrm{pO} 2$ probes, and three Rushton impellers. The fermenter was filled with $5 \mathrm{~L}$ of medium containing per liter: $20 \mathrm{~g}$ Avicel, $7.5 \mathrm{~g}$ glycerol, $1 \mathrm{~g} \mathrm{KH}_{2} \mathrm{PO}_{4}, 0.5 \mathrm{~g}$ $\mathrm{MgSO}_{4}, 7 \mathrm{~g}$ peptone, $7 \mathrm{~g}$ yeast extract. Polypropylene glycol $2000(3 \mathrm{~mL})$ was added as 
an antifoam agent and the medium $\mathrm{pH}$ was adjusted to 6.0. The fermenter was sterilized $\left(121^{\circ} \mathrm{C}, 40 \mathrm{~min}\right)$ and inoculated with $500 \mathrm{~mL}$ of homogenized mycelium grown in SM containing crystalline cellulose instead of glucose. Fermentation was performed with baffles at $27{ }^{\circ} \mathrm{C}$ and the constant airflow rate of $1 \mathrm{~L} / \mathrm{L} / \mathrm{min}$. During the fermentation process, samples were collected daily and analyzed for enzyme activity. After 8 days of fermentation, the fungal biomass was separated from the culture liquid by filtration followed by centrifugation at $6000 \mathrm{rpm}$ for $20 \mathrm{~min}$ at $4{ }^{\circ} \mathrm{C}$. The enzyme preparation was isolated from the culture liquid by precipitation with ammonium sulfate at $70 \%$ saturation and the precipitate was dissolved in $0.05 \mathrm{M}$ phosphate buffer ( $\mathrm{pH} 6.0)$.

\subsection{Wheat Straw Saccharification}

Enzymatic hydrolysis of wheat straw was carried out under standard conditions $\left(0.1 \mathrm{mM}\right.$ of citrate buffer, $\mathrm{pH} 5.0,40^{\circ} \mathrm{C}$ ) with gentle agitation at $150 \mathrm{rpm}$ for $24 \mathrm{~h}$. Pretreated with $1.5 \% \mathrm{NaOH}$ wheat straw contained $67.1 \%$ cellulose, $15.9 \%$ hemicellulose, and $7.3 \%$ lignin. Cellulase from Aspergillus niger (Sigma-Aldrich, Saint Louis, MO, USA) and crude enzyme preparations isolated (as described above) from the supernatant of I. lacteus culture in fermenter were used as enzyme sources. The reaction mixture $(10 \mathrm{~mL})$ contained 100 , 200, and $400 \mathrm{mg}$ substrate and 20 filter paper units (FPU)/g substrate. Samples were taken from the reaction mixtures after $0,3,6$, and $24 \mathrm{~h}$ of saccharification, heated in a boiling water bath for $2 \mathrm{~min}$, and then centrifuged at $10,000 \times \mathrm{g}$ for $5 \mathrm{~min}$ at $4{ }^{\circ} \mathrm{C}$. The supernatants were analyzed for reducing sugars using the dinitrosalicylic acid reagent method [11].

\subsection{Analytical Methods}

The total cellulase activity (filter paper activity, FPA) was measured with Whatman filter paper No. 1 according to IUPAC recommendations [12]. The reaction mixture containing a $50 \mathrm{mg}$ string of filter paper Whatman No. 1 (Whatman Internationl, Maidstone, UK), $0.8 \mathrm{~mL}$ of a $50 \mathrm{mM}$ citrate buffer ( $\mathrm{pH} 5.0$ ), and $0.2 \mathrm{~mL}$ appropriately diluted supernatant was incubated at $50{ }^{\circ} \mathrm{C}$ for $60 \mathrm{~min}$. Endoglucanase (CMCase) activity was assayed by mixing $70 \mu \mathrm{L}$ appropriately diluted samples with $630 \mu \mathrm{L}$ of $1 \%$ low-viscosity carboxymethyl cellulose in $50 \mathrm{mM}$ citrate buffer ( $\mathrm{pH}$ 5.0) at $50{ }^{\circ} \mathrm{C}$ for five minutes [12]. Xylanase activity was determined at the same conditions using 1\% birchwood xylan (Roth 7500) in $50 \mathrm{mM}$ citrate buffer ( $\mathrm{pH} \mathrm{5.0)}$ at $50{ }^{\circ} \mathrm{C}$ for $10 \mathrm{~min}$ [13]. Glucose and xylose standard curves were used to calculate the cellulase and xylanase activities. In all assays, the release of reducing sugars was measured using the dinitrosalicylic acid reagent method [11]. One unit of enzyme activity was defined as the amount of enzyme, releasing $1 \mu$ mol of reducing sugars per minute. To measure $\beta$-glucosidase and $\beta$-xylosidase activities, the reaction mixture containing $1.8 \mathrm{~mL}$ of $2 \mathrm{mM}$ solutions of $p$-nitrophenyl- $\beta$-D-glucopyranoside or $p$-nitrophenyl- $\beta$-D-xylopyranoside in $0.05 \mathrm{M}$ acetate buffer, $\mathrm{pH} 4.8$, and $0.2 \mathrm{~mL}$ of the enzyme solution was incubated at $50{ }^{\circ} \mathrm{C}$ for $10 \mathrm{~min}$ [14]. One unit of enzyme activity was defined as the amount of enzyme releasing $1 \mu \mathrm{mol}$ of $p$-nitrophenol per minute.

\subsection{Statistical Analysis}

All experiments were performed twice using three replicates each time. The results are expressed as the mean \pm SD. The mean values, as well as standard deviations, were calculated by the Excel program (Microsoft Office 2010 package).

\section{Results and Discussion}

\subsection{Effect of the Polymeric Carbon Sources on Basidiomycetes Enzyme Activity}

Chemically and structurally different crystalline cellulose, wheat straw, and mandarin pomace were selected as carbon sources and potential stimulators of cellulase and xylanase activities production by the three fungi. Due to the high content of sugars and organic acids, mandarin pomace ensured rapid and abundant growth of all fungi, while wheat straw showed the weakest growth. The fungi secreted large amounts of cellulase and xylanase activities regardless of the material tested; however, enzyme yields varied significantly. 
Among the three substrates tested, crystalline cellulose was found to be the best carbon source providing the highest cellulase and xylanase activity of all fungi (Table 1). This finding is in agreement with several reports showing cellulases and xylanases production by Basidiomycota species in the presence of several potential inducers [15-17].

Table 1. Modulation of basidiomycetes hydrolytic enzyme activity by chemically different growth substrates.

\begin{tabular}{|c|c|c|c|c|c|c|}
\hline $\begin{array}{l}\text { Growth } \\
\text { Substrate }\end{array}$ & $\begin{array}{c}\text { Final } \\
\mathrm{pH}\end{array}$ & $\begin{array}{l}\text { CMCase } \\
(\mathrm{U} / \mathrm{mL})\end{array}$ & $\begin{array}{l}\text { Xylanase } \\
\text { (U/mL) }\end{array}$ & $\begin{array}{c}\text { FPA } \\
(\mathrm{U} / \mathrm{mL})\end{array}$ & $\begin{array}{c}\beta \text {-Glucosidase } \\
(\mathrm{U} / \mathrm{mL})\end{array}$ & $\begin{array}{c}\beta \text {-Xylosidase } \\
(\mathrm{U} / \mathrm{mL})\end{array}$ \\
\hline 1.5\% Avicel & $5.9 \pm 0.1$ & $63 \pm 6.0^{11 *}$ & $\begin{array}{l}\text { P. coccineus } \\
31 \pm 3.8^{14 *}\end{array}$ & $4.6 \pm 0.5^{14 *}$ & $3.6 \pm 0.3^{11 *}$ & $0.06 \pm 0.01^{11 *}$ \\
\hline $\begin{array}{l}4 \% \text { mandarin } \\
\text { squeeze (MS) }\end{array}$ & $6.7 \pm 0.1$ & $19 \pm 2.1^{11}$ & $14 \pm 1.1^{8}$ & $2.2 \pm 0.2^{8}$ & $2.2 \pm 0.2^{8}$ & $0.05 \pm 0^{6}$ \\
\hline $\begin{array}{l}4 \% \text { wheat straw } \\
\text { (WS) }\end{array}$ & $6.2 \pm 0.1$ & $22 \pm 1.4^{11}$ & $18 \pm 1.2^{11}$ & $1.9 \pm 0.2^{8}$ & $1.5 \pm 0.2^{6}$ & $0.04 \pm 0^{6}$ \\
\hline $\begin{array}{c}1.5 \% \text { Avicel + } \\
4 \% \mathrm{MS}\end{array}$ & $5.6 \pm 0.1$ & $82 \pm 8.3^{14}$ & $65 \pm 5.8^{11}$ & $5.7 \pm 0.6^{11}$ & $3.3 \pm 0.3^{8}$ & $0.12 \pm 0.01^{11}$ \\
\hline $4 \% \mathrm{WS}+4 \% \mathrm{MS}$ & $5.9 \pm 0.1$ & $27 \pm 2.4^{11}$ & $\begin{array}{l}19 \pm 1.7^{11} \\
\text { S. commune }\end{array}$ & $2.2 \pm 0.3^{11}$ & $1.6 \pm 0.2^{6}$ & $0.05 \pm 0.01^{6}$ \\
\hline 1.5\% Avicel & $6.1 \pm 0.1$ & $39 \pm 4.3^{14}$ & $626 \pm 78^{14}$ & $2.1 \pm 0.3^{11}$ & $10.7 \pm 0.8^{14}$ & $0.12 \pm 0.01^{14}$ \\
\hline 4\% MS & $6.5 \pm 0.1$ & $23 \pm 3.0^{11}$ & $531 \pm 96^{8}$ & $3.0 \pm 0.3^{11}$ & $10.1 \pm 0.9^{14}$ & $0.15 \pm 0.02^{14}$ \\
\hline $4 \%$ WS & $6.8 \pm 0.1$ & $8 \pm 1.0^{14}$ & $120 \pm 10^{14}$ & $1.3 \pm 0.1^{14}$ & $3.8 \pm 0.3^{14}$ & $0.07 \pm 0.01^{14}$ \\
\hline $\begin{array}{c}1.5 \% \text { Avicel + } \\
4 \% \text { MS }\end{array}$ & $6.3 \pm 0.1$ & $39 \pm 2.9^{11}$ & $740 \pm 80^{14}$ & $4.2 \pm 0.4^{14}$ & $18.6 \pm 2.0^{14}$ & $0.31 \pm 0.03^{14}$ \\
\hline $\begin{array}{c}4 \% \mathrm{WS}+4 \% \\
\text { MS }\end{array}$ & $5.9 \pm 0.1$ & $14 \pm 1.3^{11}$ & $528 \pm 59^{6}$ & $2.2 \pm 0.2^{14}$ & $5.9 \pm 0.4^{14}$ & $0.07 \pm 0.01^{11}$ \\
\hline $\begin{array}{c}\text { 1.5\% Avicel } \\
4 \% \text { MS } \\
4 \% \text { WS }\end{array}$ & $\begin{array}{c}5.4 \pm 0.1 \\
6.9 \pm 0.1 \\
6.2 \pm 0\end{array}$ & $\begin{array}{c}54 \pm 6.6^{11} \\
18 \pm 1.4^{8} \\
23 \pm 2.0^{11}\end{array}$ & $\begin{array}{l}\text { I. lacteus } \\
67 \pm 8.1^{11} \\
20 \pm 1.7^{11} \\
29 \pm 1.4^{8}\end{array}$ & $\begin{array}{c}5.1 \pm 0.4^{11} \\
1.9 \pm 0.2^{8} \\
2.3 \pm 0.2^{11}\end{array}$ & $\begin{array}{c}1.4 \pm 0.12^{11} \\
1.1 \pm 0.12^{8} \\
1.0 \pm 0.11^{8}\end{array}$ & $\begin{array}{c}0.02 \pm 0^{6} \\
0.02 \pm 0^{6} \\
0.05 \pm 0.01^{8}\end{array}$ \\
\hline $\begin{array}{c}1.5 \% \text { Avicel + } \\
4 \% \text { MS }\end{array}$ & $5.9 \pm 0.1$ & $76 \pm 9.0^{11}$ & $106 \pm 8.6^{14}$ & $6.8 \pm 0.5^{11}$ & $2.3 \pm 0.27^{8}$ & $0.08 \pm 0.01^{8}$ \\
\hline $\begin{array}{c}4 \% \text { WS }+4 \% \\
\text { MS }\end{array}$ & $6.3 \pm 0.2$ & $40 \pm 4.7^{8}$ & $34 \pm 2.1^{8}$ & $2.5 \pm 0.3^{8}$ & $1.6 \pm 0.19^{8}$ & $0.05 \pm 0.01^{6}$ \\
\hline
\end{tabular}

* The numbers indicate the days of the peak activity.

The use of mandarin pomace as a growth substrate for S. commune allowed us to achieve comparatively high volumetric activities of all target enzymes. At the same time, the lignified material, wheat straw, induced a significant secretion of cellulase and xylanase activities of I. lacteus and P. coccineus but turned out to be a poor substrate for the production of these enzymes by S. commune. It should be noted that during the fermentation of straw and mandarin pomace the $\mathrm{pH}$ of the media was significantly higher than those in the media with Avicel, especially in the second half of the WRB cultivation. It is possible that, in this case, the hydrolysis of polysaccharides and the supply of fungi with carbon sources were limited, since the maximum catalytic activity of cellulases and xylanases of basidiomycetes is usually observed at $\mathrm{pH} 5$.

To ensure rapid and abundant initial growth of fungi, Avicel and wheat strawcontaining media were supplemented with mandarin pomace. Undoubtedly, the introduction of additional nutrition in the form of mandarin pomace favored an increase in the biomass of fungi and, accordingly, enzymatic activity. Nevertheless, the results presented in Table 1, in several variants of the experiment, clearly show the additive effect of the two substrates on the secretion of enzymes. In particular, an almost twofold increase in CMCase activity of S. commune and I. lacteus was recorded when the wheat straw-based medium was supplemented with mandarin pomace. Moreover, the xylanase activity of S. commune was increased by 4 times. Further, the presence of mandarin pomace in the Avicel-containing medium favored the accumulation of $\beta$-glucosidase and $\beta$-xylosidase by the tested fungi. 
Analysis of the profiles of enzyme production showed that they depend both on the type of fungus and the type of growth substrate. In Avicel containing cultures CMCase, xylanase, and FP activities of the fungi gradually increased and achieved maximum after 11-14 days of cultivation, while in mandarin pomace or wheat straw containing media enzyme activity in individual fungal cultures peaked after 8 days of cultivation followed by a steady decline in the activity thereafter. It is worth noting that in the cultures of $P$. coccineus and I. lacteus $\beta$-glucosidase and $\beta$-xylosidase activities achieved their maximum earlier than the polysaccharide-hydrolyzing enzymes.

Among the fungi studied S. commune appeared to be an outstanding producer of xylanase and $\beta$-glucosidase $(740$ and $18.6 \mathrm{U} / \mathrm{mL}$, respectively) whereas $P$. coccineus and $I$. lacteus were distinguished by remarkable cellulase activity (Table 1 ). The highest endoglucanase activity $(82 \mathrm{U} / \mathrm{mL})$ was revealed in the cultivation of $P$. coccineus followed by $I$. lacteus in a medium containing both Avicel and mandarin pomace as growth substrates. In the same medium, I. lacteus secreted the highest FPA $(6.8 \mathrm{U} / \mathrm{mL})$. For further study, I. lacteus was chosen not only because of the high activity of the enzymes involved in the hydrolysis of polysaccharides. This species is characterized by a high potential for colonization of a wide variety of lignocellulosic materials due to its ability to produce all the enzymes necessary for the decomposition of polymers of plant raw materials [18,19].

\subsection{Effect of Glycerol as an Additional Easily Metabolizable Carbon Source}

In a subsequent set of experiments, the effect of glycerol as an additional easily metabolized carbon source on the production of hydrolases during submerged fermentation of Avicel and wheat straw by I. lacteus was studied. There were several reasons for this. Firstly, microcrystalline cellulose and lignified straw are difficult to decompose growth substrates that slow down the initial development of fungal culture. At the same time, we observed that the use of mandarin pomace, which is characterized by a high content of sugars and organic acids, accelerates the growth of fungi and the rapid accumulation of biomass, which promotes the accumulation of enzymes. Secondly, the use of a high concentration of mandarin pomace in the nutrient medium complicates the subsequent purification of the enzyme. Thirdly, glycerol is a cheap byproduct in the biodiesel manufacturing process and an excellent carbon source for the cultivation of majority basidiomycetes. Finally, it was important to elucidate the features of the synthesis of cellulases by I. lacteus in the presence of a readily metabolizable carbon source.

The results presented in Figure 1A show that when the fungus was cultivated in a medium with crystalline cellulose, sufficiently high activity of cellulase was already detected after two days to provide the culture with a source of carbon and energy. Then the activity of the secreted enzyme rapidly increased, reaching a maximum on the tenth day of cultivation of the fungus. After this, the activity of the extracellular enzyme decreased. When the Avicel-containing medium was supplemented with glycerol, no CMCase production was observed even though the inducer was also present. It is worth noting that the higher was the glycerol concentration in the medium the longer was the period of catabolite repression of cellulase synthesis. However, when the level of available glycerol decreased, obviously due to fungal metabolism, the production of enzyme was initiated even with a higher rate than in the control culture. Nevertheless, we believe that the accelerated rate of accumulation of the enzyme, as well as the significantly increased yields of the enzyme, are simply explained by the accumulation of greater biomass of the fungus in the presence of glycerol. Interestingly, the secretion of I. lacteus xylanase followed similar production profiles as CMCase (Figure 1B), and they appeared to be co-expressed. It should be noted that the cultivation of I. lacteus in a medium containing only glycerol accompanied by an abundant growth of fungal mycelium, but very low enzyme activity. If we consider this activity as the basal level of the enzyme, then the induction ratio for I. lacteus CMCase is 67, and for xylanase-22. Thus, it can be concluded that as in many other WRB $[4,10,16]$ cellulase and xylanase of I. lacteus are inducible enzymes only in the presence of cellulose-containing materials and another mechanism of cell economy, namely, catabolite repression of the 
cellulases and xylanases synthesis, by easily metabolizable carbon sources is inherent in this fungus.
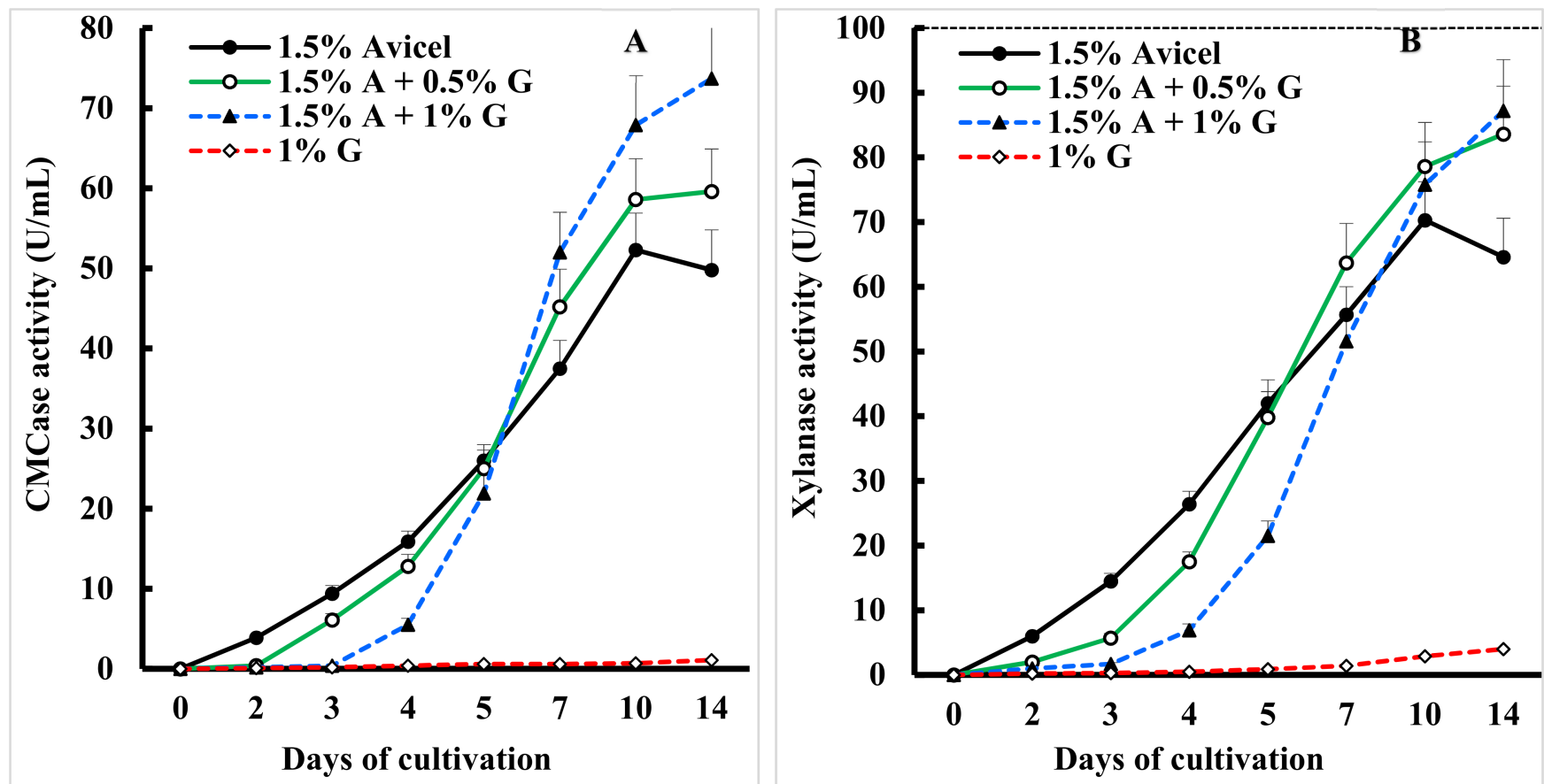

Figure 1. Effect of glycerol $(G)$ as an additional carbon source on the production of endoglucanase (A) and xylanase (B) during submerged fermentation of Avicel by I. lacteus.

\subsection{Effect of the Type of Carbon Source in the Inoculum Preparation Medium}

Recently, we showed that preliminary adaptation to the substrate in the inoculation medium may be an important factor determining the biosynthetic activity of some fungal cultures [20]. In this study, we compared the enzymatic activity of I. lacteus, an inoculum of which was grown in a standard medium with glucose as well as with crystalline cellulose as the only carbon source. We hypothesized that the inoculum prepared in the presence of Avicel would contain sufficient activities of hydrolases to start hydrolysis of polysaccharides immediately after inoculation. Moreover, this inoculum may contain oligosaccharides required to induce the synthesis of target enzymes.

Many research groups have used a wide range of agro-industrial lignocellulosic materials as inexpensive raw materials for the production of cellulases and have shown that the production of polysaccharide-hydrolyzing enzymes in WRB is influenced by the type of lignocellulosic substrate [7,8,17,21]. Therefore, besides Avicel, several cheap chemically different lignocellulosic materials were tested in this study as I. lacteus growth substrates and stimulate enzyme production. The results in Table 2 show that, regardless of the conditions of preparation of the inoculum, the highest CMCase, xylanase, and $\beta$-glucosidase activities were found when the fungus was cultivated in a medium with crystalline cellulose. Wheat straw followed by wheat bran also supported efficient secretion of these enzymes by I. lacteus. By contrast, beech sawdust appeared to be a poor substrate for the secretion of three tested enzymes. The most important finding is that replacing glucose with Avicel as a carbon source in the seed culture medium increased the activity of all enzymes in the presence of all growth substrates tested. For example, the CMCase activity of $I$. lacteus in the Avicel-containing medium increased by $38 \%$, xylanase by $50 \%$, and $\beta$-glucosidase by $72 \%$. Moreover, the use of inoculum grown in the presence of crystalline cellulose accelerated the production of target enzymes and the peaks of CMCase, and in some cases, xylanase activities were reached much earlier than when using mycelium grown on glucose. 
Table 2. Effect of the carbon source in the inoculum medium on the enzyme activity of I. lacteus.

\begin{tabular}{|c|c|c|c|c|}
\hline $\begin{array}{l}\text { Growth } \\
\text { Substrate }\end{array}$ & $\begin{array}{c}\text { Final } \\
\mathrm{pH}\end{array}$ & $\begin{array}{l}\text { CMCase } \\
(\mathrm{U} / \mathrm{mL})\end{array}$ & $\begin{array}{l}\text { Xylanase } \\
\text { (U/mL) }\end{array}$ & $\begin{array}{c}\beta \text {-Glucosidase } \\
(\mathrm{U} / \mathrm{mL})\end{array}$ \\
\hline & \multicolumn{4}{|c|}{ The inoculum was grown in the presence of glucose } \\
\hline Avicel & $5.4 \pm 0.1$ & $52.6 \pm 6.1^{11 *}$ & $71.0 \pm 6.1^{11 *}$ & $1.65 \pm 0.20^{8 *}$ \\
\hline $\begin{array}{l}\text { Mandarin } \\
\text { squeeze }\end{array}$ & $6.9 \pm 0.1$ & $11.0 \pm 0.9^{8}$ & $23.8 \pm 2.2^{14}$ & $0.87 \pm 0.06^{8}$ \\
\hline Wheat bran & $5.5 \pm 0.1$ & $17.4 \pm 1.6^{11}$ & $45.2 \pm 5.6^{11}$ & $1.18 \pm 0.16^{8}$ \\
\hline Wheat straw & $5.7 \pm 0.1$ & $29.4 \pm 3.9^{11}$ & $39.1 \pm 3.4^{11}$ & $1.34 \pm 0.14^{8}$ \\
\hline \multirow[t]{2}{*}{ Beech sawdust } & $5.7 \pm 0.1$ & $3.8 \pm 0.2^{11}$ & $10.3 \pm 1.2^{14}$ & $0.21 \pm 0.03^{11}$ \\
\hline & \multicolumn{4}{|c|}{ The inoculum was grown in the presence of Avicel } \\
\hline Avicel & $5.7 \pm 0.1$ & $72.6 \pm 8.0^{6}$ & $106.5 \pm 9.4^{11}$ & $2.84 \pm 0.21^{8}$ \\
\hline $\begin{array}{l}\text { Mandarin } \\
\text { squeeze }\end{array}$ & $7.0 \pm 0.1$ & $14.2 \pm 1.1^{6}$ & $24.5 \pm 1.9^{8}$ & $0.82 \pm 0.06^{11}$ \\
\hline Wheat bran & $6.0 \pm 0.1$ & $24.5 \pm 2.0^{11}$ & $67.2 \pm 6.0^{11}$ & $1.46 \pm 0.16^{11}$ \\
\hline Wheat straw & $5.5 \pm 0.1$ & $46.5 \pm 3.4^{6}$ & $63.2 \pm 7.1^{8}$ & $2.08 \pm 0.17^{8}$ \\
\hline Beech sawdust & $6.1 \pm 0.1$ & $4.3 \pm 0.4^{6}$ & $8.2 \pm 1.1^{8}$ & $0.38 \pm 0.03^{11}$ \\
\hline
\end{tabular}

* The numbers indicate the days of the peak activity.

\subsection{Scaled Up Enzyme Production in I. lacteus Cultivation in a Fermenter}

At the final stage, the possibility of obtaining cellulase and xylanase with a high yield was tested when cultivating the fungus in a fermenter. In the fermentation process, the medium $\mathrm{pH}$ was controlled at 6.0 for three days to prevent a decrease of medium $\mathrm{pH}$ due to the metabolism of glycerol and create optimal conditions for the rapid development of fungal culture. Then the $\mathrm{pH}$ of the medium was controlled at 5.0 to ensure optimal conditions for hydrolysis of cellulose, while after six days, when the culture entered the stationary growth phase, at 5.7, to still allow saccharification of cellulose, but prevent the accumulation of sugars and catabolic repression of enzyme synthesis by I. lacteus.

Traces of cellulase and xylanase activity were detected after two days of fungus cultivation (Figure 2). Thereafter, intense secretion of polysaccharide-hydrolyzing enzymes was observed. The activity of endoglucanase and xylanase reached its maximum after 8 days of fermentation, while FPA was picked on the seventh day of I. lacteus cultivation. The enzyme preparation $(210 \mathrm{~mL})$ isolated from the culture liquid contained $1710 \mathrm{U} / \mathrm{mL}$ CMCase, $2090 \mathrm{U} / \mathrm{mL}$ xylanase, and $150 \mathrm{U} / \mathrm{mL}$ FPA.

\subsection{Saccharification of Pretreated Wheat Straw with an Enzyme Preparation from I. lacteus}

In this study, because of the recalcitrant structure, wheat straw (WS) was pretreated with $1.5 \% \mathrm{NaOH}$ before enzymatic hydrolysis to make the polysaccharide more accessible to the enzymes. The hydrolysis of pretreated WS was compared using a commercial enzyme preparation and the crude enzyme obtained after I. lacteus cultivation in the fermenter.

At a FPA load of $20 \mathrm{U} / \mathrm{g}$ substrate, the saccharification of $10 \mathrm{mg} \mathrm{WS} / \mathrm{mL}$ for 3, 6, and $24 \mathrm{~h}$ resulted in a reducing sugar yield of $1.2,2.4$, and $4.1 \mathrm{mg} / \mathrm{mL}$, respectively (Figure 3). These concentrations represent yields from wheat straw hydrolysis of 14.5, 29.0 , and $49.4 \%$ from the theoretically possible, respectively. Doubling the concentration of the WS resulted in an increase of reducing sugars to $1.9,3.9,6.2 \mathrm{mg} / \mathrm{mL}$, respectively, but decreased their yield, respectively, to $11.4,23.5,37.3 \%$ from the theoretically possible. Finally, saccharification of $40 \mathrm{mg} \mathrm{WS} / \mathrm{mL}$ for 3,6 , and $24 \mathrm{~h}$ led to an increase of reducing sugar content up to $3.5,7.2$, and $10.7 \mathrm{mg} / \mathrm{mL}$, respectively. In this case, the yields of reducing sugars were $10.5,21.7,32.2 \%$ from the theoretically possible. Thus, the degree of hydrolysis of WS and sugar yield was dependent on the substrate concentration and incubation duration. As usual, the rate of cellulose hydrolysis first $6 \mathrm{~h}$ was high and decreased over time. One of the reasons may be the accumulation of excess end products, cellobiose and glucose, which inhibit the action of enzymes. Another reason is the partial inactivation of enzymes since enzyme preparations of I. lacteus after $24 \mathrm{~h}$ of incubation lost an average of $41 \%$ of the initial activity, while the commercial preparation lost $38 \%$. 
Interestingly, the enzyme preparation derived from I. lacteus showed a slightly higher cellulose hydrolysis potential than the commercial enzyme. This can be attributed to a more balanced mixture of enzymes and their synergistic interactions [3] as well as to a higher $\beta$-glucosidase content, which reduced the inhibitory effect of forming cellobiose. It is worth noting that recently, Mezule and Civzele [19] performed biomass hydrolysis using enzyme preparation obtained from the same strain I. lacteus but reaction mixtures containing $3 \% w / v$ of dry biomass (hay, wood or sawing residue chips, barley straw) and $0.2-0.3 \mathrm{FPU} / \mathrm{mL}$ were incubated at $\mathrm{pH} 5.5$ and $30^{\circ} \mathrm{C}$. The highest conversion yields were obtained from hay substrate, where more than $20 \%$ of the dry matter of biomass has been converted to fermentable sugar within $24 \mathrm{~h}$ of incubation. Barley straw yielded more than $0.1 \mathrm{~g}$ fermentable sugar from each $\mathrm{g}$ of dry substrate.

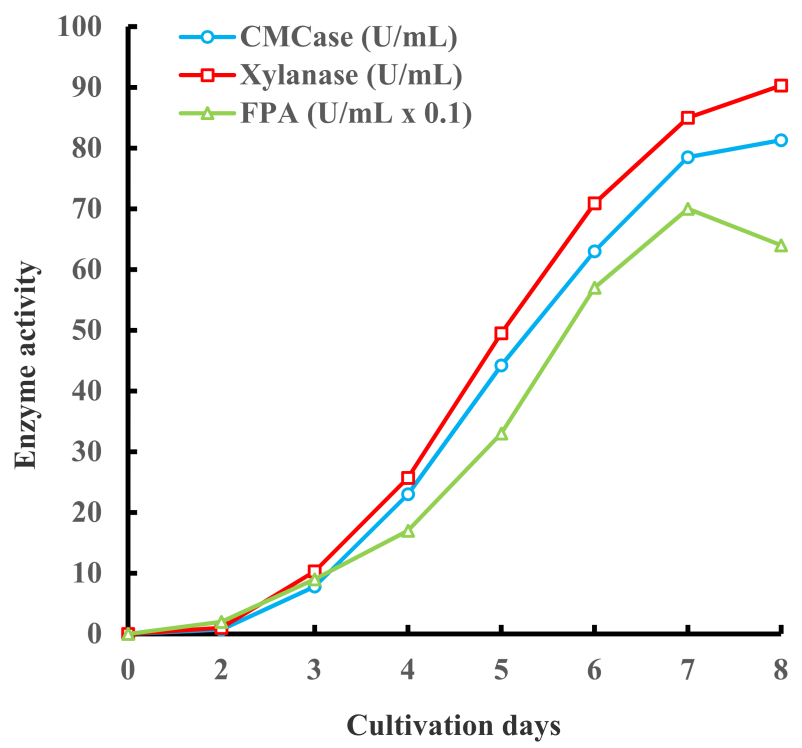

Figure 2. Kinetics of CMCase, xylanase, and FPA accumulation in I. lacteus cultivation in fermenter.

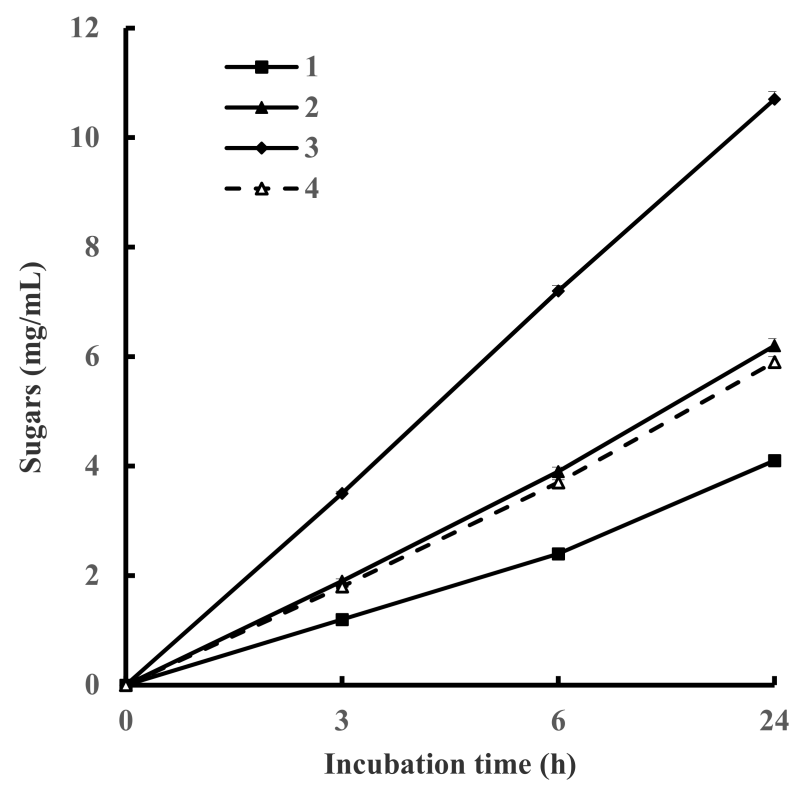

Figure 3. Accumulation of reducing sugars during hydrolysis of pretreated wheat straw (WS) using I. lacteus (1-3) and commercial (4) enzyme preparations. Enzyme load-20 U/g substrate. 1-10 mg WS; 2, 4-20 mg WS; 3-40 mg WS. 


\section{Conclusions}

Thus, I. lacteus is an excellent producer of polysaccharide-hydrolyzing enzymes, which can be used for saccharification of plant biomass with a high yield of sugars. The cellulase production system is inducible in the presence of cellulose-rich substrates but is suppressed in the presence of an excess of easily metabolizable carbon sources. Consequently, when growing fungus in a fermenter, it is necessary to create conditions that prevent the accumulation of reducing sugars in the medium. Further, the expression of cellulases and xylanases is highly dependent on the type of lignocellulosic growth substrate. The additive effect on the secretion of cellulase and xylanase of I. lacteus observed when crystalline cellulose is combined with mandarin pomace may be a good approach to increase the yield of the target enzyme. Our data show that endoglucanase and xylanase are coordinately expressed under all the conditions studied indicating that both enzymes synthesis is under a common regulatory control mechanism. Overall, this study indicates that comprehensive physiological studies are needed to improve the methods of basidiomycetes cultivation, to understand their nutritional requirements and the mechanisms of regulation of hydrolases synthesis, providing the maximum yield of target enzymes.

Author Contributions: Conceptualization: V.E.; methodology: E.M., T.K. and V.E.; validation: E.M. and T.K.; formal analysis: V.E.; investigation: E.M. and T.K.; resources: E.M.; data curation: E.M. and T.K.; writing—original draft preparation: V.E.; writing—review and editing: V.E.; visualization: V.E.; supervision: V.E.; project administration: E.M.; funding acquisition: V.E. All authors have read and agreed to the published version of the manuscript.

Funding: This research was funded by the Shota Rustaveli National Science Foundation of Georgia, project FR18-344.

Institutional Review Board Statement: Not applicable.

Informed Consent Statement: Not applicable.

Conflicts of Interest: The authors declare no conflict of interest.

\section{References}

1. Phitsuwan, P.; Laohakunjit, N.; Kerdchoechuen, O.; Kyu, K.L.; Ratanakhanokchai, K. Present and potential applications of cellulases in agriculture, biotechnology, and bioenergy. Folia Microbiol. 2013, 58, 163-176. [CrossRef]

2. Juturu, V.; Wu, J.C. Microbial cellulases: Engineering, production and applications. Renew. Sustain. Energy Rev. $2014,33,188-203$. [CrossRef]

3. Liu, L.; Huang, W.C.; Liu, Y.; Li, M. Diversity of cellulolytic microorganisms and microbial cellulases. Int. Biodeterior. Biodegrad. 2021, 163. [CrossRef]

4. Rytioja, J.; Hildén, K.; Yuzon, J.; Hatakka, A.; de Vries, R.P.; Mäkelä, M.R. Plant-polysaccharide-degrading enzymes from basidiomycetes. Microbiol. Mol. Biol. Rev. 2014, 7, 614-649. [CrossRef] [PubMed]

5. Bentil, J.A. Biocatalytic potential of basidiomycetes: Relevance, challenges and research interventions in industrial processes. Sci. Afr. 2021, 11, e00717. [CrossRef]

6. Agnihotri, S.; Dutt, D.; Tyagi, C.H.; Kumar, A.; Upadhyaya, J.S. Production and biochemical characterization of a novel cellulasepoor alkali-thermo-tolerant xylanase from Coprinellus disseminatus SW-1 NTCC 1165. World J. Microbiol. Biotechnol. 2010, 26, 1349-1359. [CrossRef]

7. Jagtap, S.S.; Dhiman, S.S.; Kim, T.-S.; Kim, I.-W.; Lee, J.-K. Characterization of a novel endo- $\beta$-1,4-glucanase from Armillaria gemina and its application in biomass hydrolysis. Appl. Microbiol. Biotechnol. 2014, 98, 661-669. [CrossRef]

8. Jagtap, S.S.; Dhiman, S.S.; Kim, T.-S.; Li, L.; Kang, Y.C.; Lee, J.-K. Characterization of a $\beta-1,4$-glucosidase from a newly isolated strain of Pholiota adiposa and its application to the hydrolysis of biomass. Biomass Bioenergy. 2013, 54, 181-190. [CrossRef]

9. Boiko, S.M. Cellulases of basidiomycetes for the development of bioconversion technologies. Ukr. Bot. J. 2020, 77, 378-385. [CrossRef]

10. Metreveli, E.; Kachlishvili, E.; Singer, S.W.; Elisashvili, V. Alteration of white-rot basidiomycetes cellulase and xylanase activities in the submerged co-cultivation and optimization of enzyme production by Irpex lacteus and Schizophyllum commune. Bioresour. Technol. 2017, 241, 652-660. [CrossRef]

11. Miller, G.L. Use of dinitrosalicylic acid reagent for determination of reducing sugar. Anal. Chem. 1959, 31, 426-428. [CrossRef]

12. Ghose, T.K. Measurement of cellulase activities. Pure Appl. Chem. 1987, 59, 257-268. [CrossRef]

13. Bailey, M.J.; Biely, P.; Poutanen, K. Interlaboratory testing of methods for assay of xylanase activity. J. Biotechnol. 1992, 23, 257-270. [CrossRef] 
14. Poutanen, K.; Pulls, J. Characteristics of Trichoderma reesei $\beta$-xylosidase and its use in hydrolysis of solubilized xylans. Appl. Microbiol. Biotechnol. 1988, 28, 425-432. [CrossRef]

15. Salmon, D.N.X.; Spier, M.R.; Soccol, C.R.; Vandenberghe, L.P.S.; Weingartner Montibeller, V.; Bier, M.C.J.; Faraco, V. Analysis of inducers of xylanase and cellulase activities production by Ganoderma applanatum LPB MR-56. Fungal Biol. 2014, 118, 655-662. [CrossRef]

16. Kobakhidze, A.; Asatiani, M.; Kachlishvili, E.; Elisashvili, V. Induction and catabolite repression of cellulase and xylanases synthesis in the selected white-rot Basidiomycetes. Ann. Agric. Sci. 2016, 14, 169-176. [CrossRef]

17. Sornlake, W.; Rattanaphanjak, P.; Champreda, V.; Eurwilaichitr, L.; Kittisenachai, S.; Roytrakul, S.; Fujii, T.; Inoue, H. Characterization of cellulolytic enzyme system of Schizophyllum commune mutant and evaluation of its efficiency on biomass hydrolysis. Biosci. Biotechnol. Biochem. 2017, 81, 1289-1299. [CrossRef]

18. Qin, X.; Su, X.; Luo, H.; Ma, R.; Yao, B.; Ma, F. Deciphering lignocellulose deconstruction by the white rot fungus Irpex lacteus based on genomic and transcriptomic analyses. Biotechnol. Biofuels 2018, 11, 58. [CrossRef]

19. Mezule, L.; Civzele, A. Bioprospecting white-rot basidiomycete Irpex lacteus for improved extraction of lignocellulose-degrading enzymes and their further application. J. Fungi 2020, 6, 256. [CrossRef]

20. Kachlishvili, E.; Kobakhidze, A.; Rusitashvili, M.; Tsokilauri, A.; Elisashvili, V. Elucidation of the higher basidiomycetes' enzyme activity dependence on the mushroom inoculum form, pre-cultivation medium, age, and size. Int. J. Med. Mushrooms 2020, 22, 1099-1108. [CrossRef]

21. Manavalan, T.; Manavalan, A.; Thangavelu, K.P.; Heese, K. Characterization of a novel endoglucanase from Ganoderma lucidum. J. Basic Microbiol. 2015, 54, 761-771. [CrossRef] [PubMed] 